\title{
The male of Mischocyttarus nomurae Richards, with a re-examination of the limits and contents of the M. cerberus species group (Hymenoptera, Vespidae, Polistinae, Mischocyttarini)
}

\author{
Orlando Tobias Silveira ${ }^{1}$
}

${ }^{1}$ Coordenação de Zoologia; Museu Paraense Emílio Goeldi/MCT. Avenida Perimetral, Terra Firme, 66040-170 Belém-PA, Brasil.

\begin{abstract}
Resumo. O macho de Mischocyttarus nomurae Richards, com um re-exame dos limites e conteúdo do grupo de espécies de $M$. cerberus (Hymenoptera, Vespidae, Polistinae, Mischocyttarini). Descreve-se pela primeira vez o macho de $M$. nomurae Richards, 1978 discutindo-se também suas relações com outras espécies similares, num contexto de redefinição dos limites do grupo de espécies de M. cerberus.
\end{abstract}

Palavras-chave. Chapada Diamantina; Mischocyttarus cerberus; Mischocyttarus nomurae; Polistinae; Vespidae.

Aвstract. The male of Mischocyttarus nomurae Richards, 1978 is described for the first time, and relationships between this and other similar species are discussed in a context of redefining the limits of the M. cerberus species group.

Keywords. Chapada Diamantina; Mischocyttarus cerberus; Mischocyttarus nomurae; Polistinae; Vespidae.

Mischocyttarus de Saussure, 1853 is the largest genus among social vespids, with more than two hundred described species. Colony organization corresponds to a social grade recognized by JEANNE (1980) as the "independent founders" wherein a colony is founded by a solitary female or a small group of associated "foundresses". Modern taxonomy of the genus has been worked mainly by RiCHARDS $(1945,1978)$, ZIKÁN (1949), and more recently by COOPER (1996a, 1996b, 1997a, 1997b, 1998a, 1998b), and SiLVEIRA (1998, 2002).

Mischocyttarus nomurae was described by RICHARDS (1978) based on two female specimens and nest from the Brazilian State of Ceará. The author assigned the species to his subgenus Haplometrobius Richards, 1978 and within that to the species group of M. artifex (Ducke, 1914). The latter assignment is incorrect in the context of Richards' species groups because $M$. nomurae shares distinctive features with $M$. cerberus Ducke, 1918. In addition, as it will be shown, these features are shared by a few other species previously considered as members of the M. artifex and M. surinamensis groups (RICHARDS 1978; COOPER 1998b), these facts implying changes in the contents of the groups.

Problems with Richards' species groups in the subgenus Haplometrobius were treated by COOPER (1998b) in a paper on the $M$. artifex group. The author comments on the difficulties of distinguishing this group from that of M. iheringi Zikán, 1935 concluding that "... the separation of the artifex and iheringi groups is therefore arbitrary". While not necessarily agreeing with Cooper, I similarly think that differentiating the cerberus and artifex groups is impractical with the characters given by RicHARDS (1978). Reading of couplet 65 in RichARDS' key (1978: 395) indeed gives the impression that characters may be unimportant for recognition of groups. However, as it is often the case with many of Richards' notions, his species groups represent useful concepts for systematic research in Mischocyttarus if adequately reworked. So, in this paper, besides describing the male of $M$. nomurae Richards, collected in "Chapada Diamantina" in the Brazilian State of Bahia, an argument is presented on the close relationship of this species with M. cerberus Ducke and some other species, and simultaneously redefining the M. cerberus group.

\section{Mischocyttarus nomurae Richards, 1978}

(Figs. 1-5)

Male. Size small, length of fore wing $8 \mathrm{~mm}$; head in frontal view not much wider than high; clypeus slightly higher than wide, ratio height/width 1.04, ventral margin broadly round; malar space obsolete; tentorial pit much closer to eye than to antennal socket (Fig. 1); antenna with the scape relatively short, 2.5 times longer than wide; flagellomeres with tyloids rather flat but distinct, shining; ventral surface of antenna lacking noticeable hairs (Richards' "cilia"); no antennomeres flattened below; apex of the antenna rather elongate, spirally rolled, antennomere 13 about 3.8 times longer than wide, 1.3 times longer than antennomere 12 (Fig. 2); mandible with only three teeth, the lowermost one far larger than the others (Fig. 1); gena very narrow; posterior ocelli separated by distance larger than one diameter, POL/OOL about 0.7 ; occiput unmargined; pronotum without lateral fovea, the anterior margin with the lamella wide and well raised but not reflexed, region just behind produced into a sharp secondary margin; carina high and salient, ending abruptly at sides, almost straight from above, humeral angle not lobate; mesoscutum slightly shorter than wide; fore wing moderately elongate, ratio between length of discal cell and height of mesepisternum about 2.25; inner claw of hind tarsus very narrow; propodeum with a shallow wide 
posterior cavity, without a central carina; propodeal valvula in lateral view rather high, widely round; first segment of metasoma short, its length about 0.9 times the height of mesepisternum, with the sides diverging quite regularly to the apex, this region not campanuliform, spiracles not prominent.

Genitalia. Aedeagus curved in lateral view, from above with the distal half narrow, then expanding to form a well differentiated apex whose lateral contour is more or less round (Fig. 5); ventral process of the aedeagus as a rounded lobe, not very large; parameral spine with long moderately numerous hairs distributed on the bulbous part of the spine (Fig. 4); digitus very long, its shape poorly defined distally, more or less as a wrinkled paper bag, not distinctly "digitiform" (Fig. 4a); digitus bare, at most with very small whitish hairs visible only at high magnification.

Vestiture. Clypeus and upper plate covered by dense recumbent hairs with silvery reflections; mandible without such a dense cover of hairs; eyes with very short sparse setae.

Color. Black, except for the following yellow areas: mandible, clypeus and upper plate, a genal band, two very weak oblique streaks behind ocelli, ventral inner surface of antenna, pronotal carina, hind margin and ventral lateral angle of pronotum, two weak streaks on mesoscutum, large median ventral area on mesepisternum, small spot above articulation of mid coxa, spot on dorsal mesepisternal plate, anterior spots on scutellum and axilla, most of metanotum, part of upper metapleural plate, two large paired spots on propodeum, valves, ventral surface of mid coxa, two elongate spots on hind coxa, basal and apical spots on femora, apical spot on fore tibia, small basal spot on metasomal tergum 1, distal marginal bands on terga and sterna. Wing membrane hyaline, veins dark brown.

Variation. The single female from Lençóis (BA) differs from the two types collected in Fortaleza (CE) in having the apex of the clypeus slightly wider and very weakly bidentate, the first segment of the metasoma a little shorter, and the dark marks more developed specially on face and clypeus. This kind of character variation is also found within M. cerberus, and thus is not a compelling reason to question the conspecificity of the two forms from northeastern Brazil.

Examined material. BRASIL. Ceará: Fortaleza, 2 females (Holotype, Paratype), 30/V/1965, H. Nomurae coll. (Museu de Zoologia, Universidade de São Paulo, São Paulo). Bahia: Lençóis, Chapada Diamantina, 1 female, 1 male, 12-19/I/1997, O.T. Silveira coll. (Museu Paraense Emílio Goeldi, Belém).

\section{DISCUSSION}

Original limits of the M. cerberus group. RICHARDS (1978: 423) established a group for M. cerberus Ducke and M. schadei Zikán, 1949 based on the following principal characteristics: (1) pronotum with a sharp secondary margin behind the anterior lamella; (2) fovea absent; (3) proepisternum in front "either raised and reflexed or not"; (4) inner claw of hind tarsus "more or less sharp"; (5) male antenna spirally rolled at apex with last three segments elongate, (6) no segment ciliated; (7) larva with two short parallel blunt-ended lobes on first abdominal sternum, (8) the lobes with pale bristles throughout, (9) other sterna without bristles.

Richards intended to give formal recognition to well marked differences between $M$. cerberus and M. artifex and allied species. However, erroneous inclusion of M. schadei forced him to make vague assertions as in characters 3 and 4 above. Examination of the holotype of $M$. schadei revealed that this species is closely related to M. ypiranguensis Fonseca, 1926 and M. mirificus Zikán, 1935 both species assigned by RichaRDS (1978) to the group of M. artifex. These three very similar forms from southeastern South America differ from M. cerberus in most characters except 1,2 and 6, which indeed show rather wide distribution within the genus. So in the context of Richards' species groups, M. schadei should be transferred to the group of M. artifex.

A more precise definition and extended content. After eliminating ambiguities in characters 3 and 4 as stated by Richards, and adding other characters, including features of the male genitalia it is then possible to see a well coordinated set of characters defining a group of $M$. cerberus, actually more inclusive than previously acknowledged. Most of these characters have been observed in the species $M$. dimorphus Zikán, 1949, M. nomurae Richards, 1978, M. peruanus Zikán, 1949, and M. narinensis Cooper, 1998 and their occurrence may also be inferred in M. illusorius Richards, 1978 (based on COOPER 1998b, and RichARDS 1978).

All species above have the posterior ocelli fairly separated by a distance larger than one ocellus diameter. This feature may be found in several other groups of Mischocyttarus, but is rarely seen in other Haplometrobius, actually only in a few species of the iheringi group. The occiput is completely round, neither margined nor compressed, and the female clypeus is wider than in most species of the subgenus. The inner claw of hind tarsus is narrow (Fig. 3), not really sharp but different from the spoon-shaped condition found in species of the artifex group, including $M$. schadei.

A typical feature of $M$. cerberus is the relatively short first metasomal tergum with the sides diverging quite regularly from base to apex. There is no apical campanula as that observed in many species of the genus. Among the species here assigned to the cerberus group only $M$. nomurae has a more distinctly campanulate first tergum. Because some species of the group of M. surinamensis (de Saussure, 1854) with a short first segment approach the shape observed in M cerberus, and since both groups have the margin of the proepisternum raised and reflexed, Richards erroneously considered $M$. peruanus as a member of the surinamensis group. The examined holotype of M. peruanus is indeed very similar to the male of M. cerberus, and a case is thus made for removal of the species to the group of M. cerberus.

The male mandible in this group of $M$. cerberus has only three teeth, the lowermost one being distinctly larger than the two others (Fig. 1). A very large first tooth is also found in most species of the group of M. artifex (but not in M. artifex 

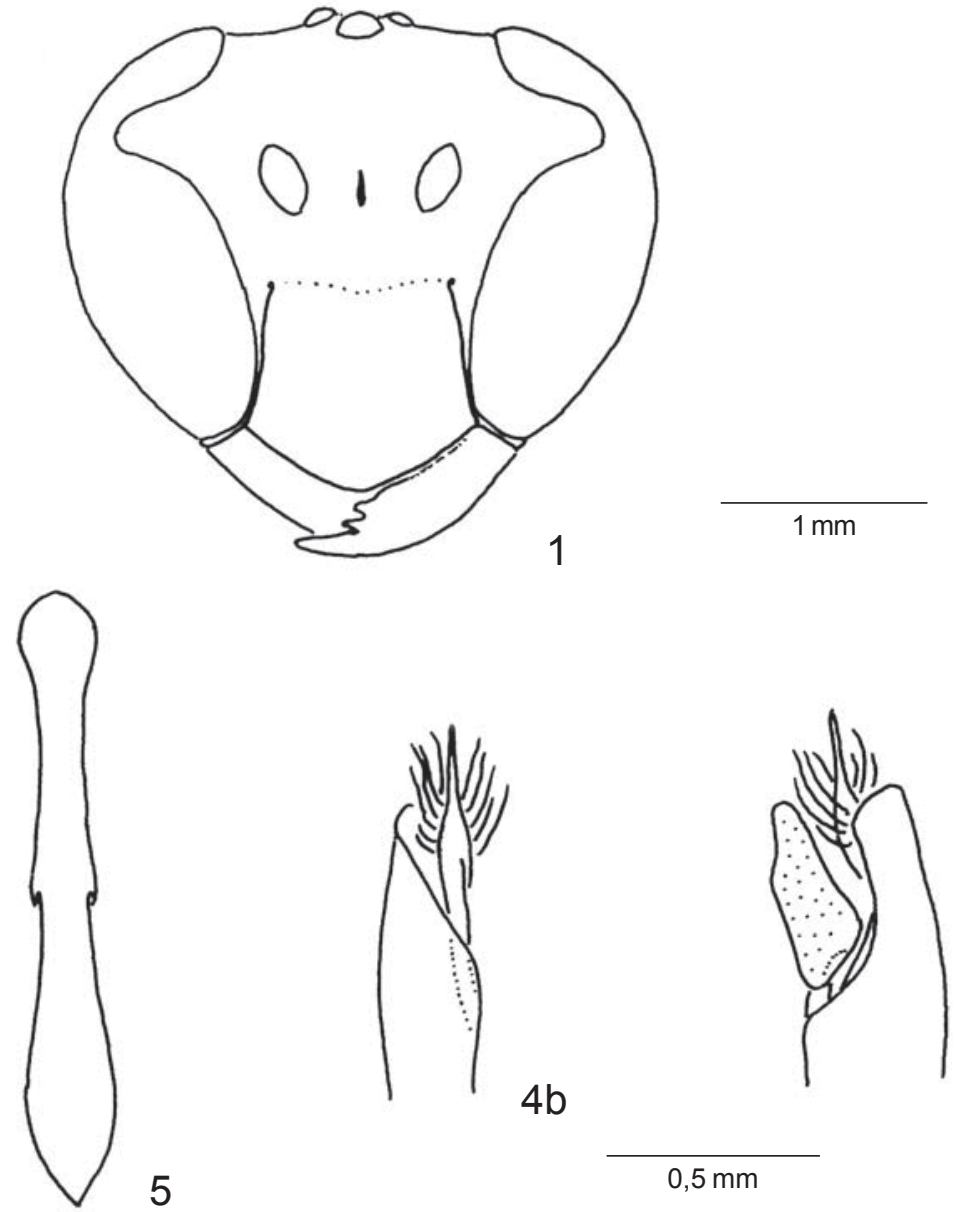

$4 a$

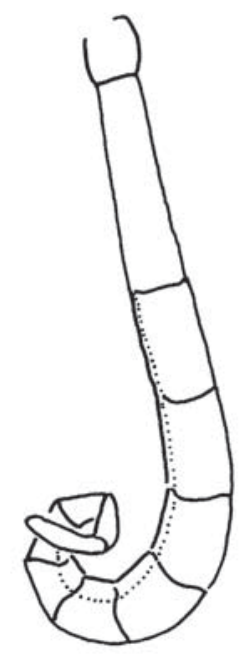

$0,5 \mathrm{~mm}$

Figs. 1- 5. Mischocyttarus nomurae. 1, general aspect of the male head; $\mathbf{2}$, lateral view of the male antena; $\mathbf{3}$, aspect of the inner (larger) claw of the female hind tarsus; $\mathbf{4 a}$, ventral aspect of right paramere with spine, and digitus of the male genitalia; $\mathbf{4} \mathbf{b}$, dorsal aspect of right paramere with spine; 5, dorsal aspect of the male aedeagus.

proper, nor in M. schadei, M. mirificus and M.ypiranguensis), and in the subgenus Kappa de Saussure, 1854. Regarding the male genitalia, the dissections made of M. cerberus, M. nomurae and M. narinensis (Colombia, Valle, Buenaventura, Bajo Calima, Rio Calima, 40 m, 8/IX/1995, C. Sarmiento coll.) revealed that two characters are apparently unique in $M$. cerberus and allies: the shape of the digitus (Fig. 4a) very long but not definitely "digitiform" as in Kappa or Phi de Saussure, 1854 and the parameral spine with moderately numerous elongate hairs (Fig. 4). Most species of the M. artifex group have the digitus shorter and triangular, and the parameral spine is nearly glabrous.

Diagnosis of the $M$. cerberus group. Posterior ocelli separated by distance ca. 1.5 times larger than one diameter; pronotum with a sharp secondary margin behind the anterior lamella; fovea absent; proepisternum in front raised and reflexed; inner claw of hind tarsus narrow, never spoonshaped; male antenna spirally rolled at apex with last three flagellomeres elongate, no antennomere ciliated; male mandible with three teeth, the lowermost one much larger than the other teeth; male genitalia with the digitus very long but not definitely "digitiform", parameral spine with moderately numerous elongate hairs.

\section{CONCLUDING REMARKS}

Study in progress on the phylogenetic relationships within Mischocyttarus (SILveIRA, unpublished) has shown that the group of M. cerberus as defined here is monophyletic, supported by unique transformations of the characters of the male genitalia above, as well as by homoplastic transformations involving some other characters mentioned. However, evidence on relationships of the group is ambiguous, analyses either showing it as part of a larger clade with elements of the $M$. artifex group, or otherwise as related to other groups of Haplometrobius and even other subgenera.

As stated before, M. illusorius Richards is probably a member of the $M$. cerberus group. In spite of the species' male being unknown, M. illusorius presents all five sex-independent characters mentioned in the diagnosis above, and such a 
combination has been observed only in the species here assigned to the group. These species can be identified with the key presented below (see also Richards 1978, and COOPER 1998b), except for the case involving M. peruanus. Apart from being very small, the holotype male of this species seemed indistinguishable from $M$. cerberus, and synonymy is to be considered in further studies. In particular, females in the Weyrauch collection at Tucumán, mentioned by RichARDS (1978) should be examined.

Provisional key for species of the M. cerberus group

1. Anterior margin of pronotum with a small, central fenestra (eastern Andes of Peru) M. illusorius Richards

Anterior margin of pronotum without a fenestra 2

2(1). Pronotal carina very high and salient, ending quite abruptly at sides; metanotum distinctly flattened; male mandible at base with not very numerous fine silvery hairs similar to those of clypeus, these parts largely yellow

Pronotal carina ending more gradually at sides; metanotum more convex; male mandible at base with a dense cover of fine silvery hairs similar to those of clypeus, these parts largely black

3(2). Black species with extensive yellow marks (NE Brazil) ... M. nomurae Richards

Yellow species with black or brown marks (South America east of the Andes)

M. cerberus Ducke, M. peruanus Zikán

4(2). Pronotal carina curved at sides forming a rounded lobe; male frons and metasomal terga black (eastern Andes of Peru) M. dimorphus Zikán

Pronotal carina weakly developed at sides, not forming a rounded lobe; male frons yellow with a bifid mark, metasomal terga brown (Pacific coast of Colombia).. M. narinensis Cooper
Acknowledgments. I am grateful to Ligia, Roy and Rafael Funch for their hospitality in Lençóis, and for showing to Angela and me the magnificence of Chapada Diamantina. Dr. Sérvio T. P. Amarante facilitated a loan of the types of M. nomurae, and Dr. James Carpenter kindly read the manuscript.

\section{REFERENCES}

Cooper, M. 1996a. The subgenus Monogynoecus Richards of Mischocyttarus de Saussure (Hym., Vespidae, Polistinae) with descriptions of two new species. Entomologist's Monthly Magazine 132: 23-28.

Cooper, M. 1996b. The mendax group of Mischocyttarus (Hym., Vespidae, Polistinae) with descriptions of new species. Entomologist's Monthly Magazine 132: 273-280.

Cooper, M. 1997a. A new subgenus of Mischocyttarus de Saussure (Hym., Vespidae). Entomologist's Monthly Magazine 133: 117-129.

Cooper, M. 1997b. The subgenus Megacanthopus Ducke of Mischocyttarus de Saussure (Hym., Vespidae), with a key and three new species. Entomologist's Monthly Magazine 133: 217-223.

Cooper, M. 1998a. Two new species of Mischocyttarus (Hym., Vespidae) with notes on some members of the iheringi group. Entomologist's Monthly Magazine 134: 89-93.

Cooper, M. 1998b. New species of the artifex group of Mischocyttarus de Saussure (Hym., Vespidae) with a partial key. Entomologist's Monthly Magazine 134: 293-306.

Jeanne, R. L. 1980a. Evolution of social behavior in the Vespidae. Annual Review of Entomology 25: 371-396.

Richards, O. W. 1945. A revision of the genus Mischocyttarus de Saussure (Hymen., Vespidae). Transactions of the Royal Entomological Society 95: 295-462.

Richards, O. W. 1978. The social wasps of the Americas excluding the Vespinae. London, British Museum (Natural History), $580 \mathrm{p}$.

SilveIRA, O. T. 1998. Mischocyttarus (Mischocyttarus) aripuanaensis. A new social wasp from western-central Brazil, and redescription of Mischocyttarus lindigi Richards (Hym., Vespidae, Polistinae). Papéis Avulsos de Zoologia 40: 359-367.

Silveira, O. T. 2002. Mischocyttarus acunai Alaio: A Caribbean member of the subgenus Mischocyttarus s. str. de Saussure (Hymenoptera: Vespidae; Polistinae). Natural History Bulletin of Ibaraki University 6: 7-10.

ZIKÁN, J. F. 1949. O gênero Mischocyttarus Saussure (Hymenoptera, Vespidae), com a descrição de 82 espécies novas. Boletim do Parque Nacional do Itatiaia 1: 1-125. 